\title{
REPRESENTASI PRAKTEK PERBUDAKAN DAN PENINDASAN DALAM PUISI 'NEGRO’ KARYA LANGSTON HUGHES: SEBUAH KAJIAN POSKOLONIAL
}

\author{
Ila Amalia \\ UIN Sultan Maulana Hasanuddin Banten \\ Email: ilaamalia0401@gmail.com
}

\begin{abstract}
(Title: Representation of Slavery and Oppression Practices in 'Negro' Poetry by Langston Hughes: A Postcolonial Study). This study aims to describe the forms of oppression and slavery practices caused by racial discrimination and colonialism practices. With a background of slavery experienced by blacks in this case the African nation, the analysis of this poem aims to see how: (1) The form of slavery and oppression carried out by the colonials against the colonized people depicted in the poem "Negro" by Langston Hughes, (2) Forms of struggle and response carried out by colonized nations towards the practice of oppression illustrated in the poem "Negro" by Langston Hughes. The postcolonial theory approach is used as a foundation in the analysis of poetry. The data source is taken from a poem by Langston Hughes with the theme of discrimination and racial subordination of African-Americans entitled "Negro" written in 1922. The results show that black people have experienced oppression in the form of slavery, forced/ hard workers, victims of cruelty, and art workers who express their stories and historical experiences through their songs. One of the efforts made by colonized nations to fight against colonial practices is through civil movements, including through literary works. Later this civil movement led to the discourse of the abolition of slavery throughout the world.
\end{abstract}

Keywords: postcolinial, colonialism, oppression, slavery, Africa

\section{PENDAHULUAN}

Kajian poskolonial merupakan kajian lintas disiplin, yang dilatarbelakangi oleh satu momen historis yang sama, yakni kolonialisme. Melalui berbagai praktik dan bentuknya, seperti pendudukan, perbudakan, pemindahan penduduk, pemaksaan bahasa, atau penggantian budaya, kolonialisme telah menghancurkan sendi-sendi kehidupan dan kebudayaan masyarakat jajahan. Munculnya poskolonial, dalam konteks ini, dimaksudkan untuk mengembalikan atau memulihkan keutuhan dan kekuasaan masyarakat yang telah dimarjinalkan atau termarjinalkan oleh proses-proses kolonialisasi tersebut. Menurut Ashcroft (2003), teori ini lahir sesudah kebanyakannegara-negaraterjajahmemperoleh kemerdekaannya, yaitu sekitar tahun 1960an.

Cikal bakal kelahiran teori postkolonial diawali dengan terbitnya buku Edward W. Said yang berjudul Orientalism pada tahun 1978.
Dalam bukunya tersebut Said menggunakan pendekatan hubungan antara kekuasaan dan pengetahuan. Pada buku tersebut Said memedakan tiga penggunaan istilah orientalisme yaitu: (1) menunjukan periode relasi budaya dan politik antara Eropa (Barat) dan Asia (Timur), (2) menunjukan studi akademik yang berkaitan dengan bahasa dan budaya Asia yang perjanjiannya dilaksanakan pada aal abad ke-19, (3) berkaitan dengan pandangan stereotype terhadap Asia Timur yang dikembangkan oleh para ahli (penulis barat).

Menurut Said kaum orientalis berpendapat bahwa masalah studi ilmiah Barat mengenai Timur tidaklah semata-mata didorong oleh kepentingan pengetahuan, tetapi juga kepentingan kolonialisme. Pengetahuan bagi kaum Orientalis adalah untuk mempertahankan kekuasaanya, yakni pengetahuan yang dipenuhi dengan visi dan misi politis ideologis. Studi 
tersebut juga semata-mata merupakan bentuk lain atau kelanjutan dari kolonialisme. Bangsa Timur dikontruksikan sebagai bangsa yang identik dengan irasionalitas, berakhlak buruk, kekanak-kanakan, dan "berbeda" dengan Barat yang rasional, bijaksana, dewasa, dan "normal" (Santosa, 2018).

Berdasarkan pandangan said terhadap kolonialisme ini maka muncul teori poskolonial yang ingin menghapuskan praktek-praktek kolonialisme yang telah melahirkan kehidupan yang penuh dengan rasisme, hubungan kekuasaan yang tidak seimbang, bukan dengan propaganda peperangan dan kekerasan fisik, tetapi didialektikakan melalui kesadaran atau gagasan. Dengan perkataan lain, poskolonial sebagai alat atau perangkat kritik yang melihat secara "jernih" bagaimana sendisendi budaya, social dan ekonomi digerakkan untuk kepentingan kelas dominan atau pusat (Kusmarni, 2019).

Menurut Ashcroft dkk (1989) dalam bukunya The Empire Writes Back istilah poskolonial itu sendiri mengacu pada beberapa hal. Pertama, istilah poskolonial sering digunakan untuk membedakan masa sebelum dan sesudah kemerdekaan (masa kolonial dan masa poskolonial). Kedua, istilah poskolonial juga mencakup seluruh kebudayaan yang pernah mengalami kekuasaan imperial dari awal sejarah kolonisasi hingga kurun waktu sekarang. Ketiga, istilah poskolonial juga merupakan istilah yang paling tepat untuk menyebut kritik-kritik lintas budaya yang muncul akhir-akhir ini serta wacana yang dibentuknya.

Sementara, poskolonial menurut Kutha Ratna (2008) adalah teori yang digunakan untuk menganalisis berbagai gejala kultural, seperti sejarah, politik, ekonomi, sastra dan sebagainya, yang terjadi khususnya di negara bekas koloni Eropa modern. Pada umumnya gejala-gejala kultural tersebut terkandung dalam berbagai teks studi mengenai dunia Timur, yang ditulis oleh para orientalis, yang disebut sebagai teksteks oriental. Meskipun demikian, sebagai akibat dominasi intelektualitas Barat, banyak juga karya yang melukiskan ketidakseimbangan hubungan Barat-Timur, yang ditulis oleh kaum terpelajar pribumi yang telah terkonstruksi oleh pemikiran Barat.

Seperti yang ditulis oleh Kutha Ratna (2008) bahwa teori poskolonial adalah teori yang digunakan untuk menganalisis berbagai gejala kultural, seperti sejarah, politik, ekonomi, sastra dan sebagainya, yang terjadi khususnya di negara bekas koloni Eropa modern. Serupa dengan itu, Emzir dan Rohman (2017) menegaskan bahwa post-kolonialisme kerap digunakan sebagai sebuah pendekatan dalam analisis sastra. Tulisan-tulisan yang dikaji umumnya merupakan tulisan dari budaya bangsa-bangsa yang pernah dijajah seperti Australia, Selandia Baru, Afrika, Amerika Selatan, dan bangsa-bangsa bekas jajahan lain atau masyarakat yang dulu didominasi.

Dengan demikian, sejumlah tulisan karya sastra yang lahir di wilayah negaranegara tersebut pun, dapat menjadi obyek kajian yang menarik, karena di sana dapat ditemukan beragam permasalahan, seperti krisis identitas, perbudakan, pengasingan, hegemoni, dan berbagai bentuk invasi kultural lainnya. Terkait dengan bagaimana melihat dua budaya bertemu dan bertentangan misalnya budaya kulit putih dan kulit hitam. Perhatiannya seperti pada isuisu nasionalisme dan mencoba mengekspos perlakuan terhadap bangsa Afro-Amerika, misalnya, sebagai sub budaya yang tertindas, tertekan, terjajah oleh penjajah kulit putih.

Beberapa penelitian yang membahas karya sastra khususnya yang dilaterbelakangi sejarah kolonialisme yang dialami oleh bangsa kulit hitam sudah banyak dilakukan. Salah satu yang menjadi perhatian adalah karya sastra yang dihasilkan oleh penulis Langston Hughes, seorang penulis kelahiran Amerika keturunan Afrika yang mencoba menggambarkan penderitaan dan perjuangan kaum kulit hitam yang diakibatkan oleh praktek kolonialisme dan praktek diskriminasi rasial.

Dalam penelitiannya Iswalono (2014) menemukan bentuk dan respon terhadap hegemoni rasial serta jati diri etnik AfroAmerika dalam tiga puisi karya Hughes yang berjudul I, Too, Sing America, Let America be America Again, dan Theme for English B. Terdapat bentuk serta respon terhadap hegemoni 
rasial yang dialami oleh etnik Afro-Amerika yaitu (1) hegemoni rasial muncul dalam bentuk stereotyping negative, (2) respon atas hegemoni rasial berupa kesadaran etnik Afro-Amerika akan martabat, harga diri, dan kepercayaan diri sebagai pijakan menuntut kesetaraan dan menunjukkan eksistensi di tengah dominasi etnik kulit putih, (3) kebanggaan jati diri etnik sesungguhnya merupakan potensi dalam mewujudkan cita-cita Amerika sebagai negara yang mengedepankan kesetaraan dalam kemajemukan sebagaimana diidamkan oleh para pendiri bangsa.

Sementara penelitian yang dilakukan oleh Riana, Nova M dkk. (2015) menganalisis puisi Langston Hughes dengan judul The Mother to Son, Trumpet Player dan The Negro Speaks of Rivers dengan menggunakan pendekatan semiotika puisi. Hasil penelitian menunjukan bahwa makna signifikansi dari tiga puisi Hughes adalah sebuah pemikiran liberalisme dan liberalisme disini terdiri dari kebebasan dan keadilan individu dalam masyarakat.

Berdasarkan penjelasan di atas maka penelitian ini bermaksud akan menganalisis salah satu karya sastra yang ditulis oleh penulis kulit hitam yaitu Langston Hughes yang berjudul Negro. Puisi Negro adalah sebuah puisi yang memotret perjuangan kaum AfricanAmerika di Amerika yang menghadapi berbagai perlakuan akibat praktek kolonial di masa lampau. Kaum kulit hitam (Afrika-Amerika) seringkali menghadapi perlakuan yang tidak adil dan dikriminatif yang disebabkan oleh latar belakang sejarah kaum ini dimasa lampau yang diidentikan dengan perbudakan. Lebih jauh penelitian ini bertujuan untuk menganalisis representasi praktek perbudakan dan penindasan kaum kulit hitam dalam Puisi Negro.

\section{METODE}

Penelitian ini menggunakan metode deskriptif kualitatif dengan pendekatan poskolonialisme. Dengan menerapkan teori postkolonial, penelitian ini bertujuan untuk menemukan, mema-parkan, dan menganalisa penindasan dan diskriminasi rasial yang diakibatkan oleh praktek kolonilaisme.
Lebih spesifik tujuan penelitian adalah untuk menjawab pertanyaan berikut ini; (1) Bagaimanakan bentuk penindasan yang dilakukan oleh kaum kolonial terhadap kaum bangsa terjajah yang tergambar pada puisi "Negro" karya Langston Hughes? (2) Bagimana perjuangan dan respon yang dilakukan oleh kaum bangsa terjajah terhadap praktek penindasan yang tergambar pada puisi "Negro" karya Langston Hughes? Sumber data utama dari penelitian ini adalah puisi karya Langston Hughes yang bertema diskriminasi dan subordinasi rasial kaum Afrika-Amerika yang berjudul "Negro". Sementara sumber data sekunder diperoleh melalui buku, artikel penelitian terdahulu, serta sumber dari internet. Penelitian ini menggunakan data yang berupa cuplikan kata, frasa, atau ekspresi yang ada di dalam puisi "Negro".

Teknik pengumpulan dan analisis data dilakukan dengan menggunakan teknik membaca tekun karya puisi "Negro". Teknik membaca tekun dilakukan untuk memperoleh makna tersirat maupu tersurat dari puisi Negro. Untuk mendapatkan makna secara komprehensif dari puisi Negro, berbagai data tambahan diperlukan dalam bentuk buku-buku rujukan, hasil penelitian yang relevan, serta sumber dari internet.

\section{HASIL DAN PEMBAHASAN}

Penelitian ini bertujuan untuk menemukan, memaparkan, dan menganalisa penindasan serta praktek perbudakan yang diakibatkan oleh diskriminasi rasial dan praktek kolonialisme. Lebih spesifik tujuan penelitian adalah untuk menjawab pertanyaan sebagai berikut: (1) Bagaimana bentuk perbudakan dan penindasan yang dilakukan oleh kaum kolonial terhadap kaum bangsa terjajah yang tergambar pada puisi "Negro" karya Langston Hughes? (2) Bagimana perjuangan dan respon yang dilakukan oleh kaum bangsa terjajah terhadap praktek penindasan yang tergambar pada puisi "Negro" karya Langston Hughes? Sumber data penelitian ini adalah puisi karya Langston Hughes yang bertema diskriminasi dan subordinasi rasial kaum Afrika-Amerika yang berjudul "Negro". 
Puisi "Negro" karya Langston Hughes berkaitan dengan deskripsi umum tentang sejarah orang Afrika-Amerika atau bangsa kulit hitam sepanjang sejarah praktek perbudakan dan kolonialisme. Melalui karya sastra ini Hughes ingin berbagi pengalaman dengan pembaca tentang pengalaman bersejarah orang kulit hitam dan menunjukkan beberapa perlakuan yang diterima orang kulit hitam sebagai dampak dari praktek kolonialisme di era masa lalu dan masa sekarang.

Kelahiran puisi "Negro" tidak terlepas dari situasi social politik yang terjadi pada masa itu di benua Amerika Serikat. Pada awal abad ke duapuluh perjuangan untuk melawan diskriminasi rasial terjadi secara besar-besaran di Amerika Serikat. Berbagai unsur dari warga Amerika keturunan Afrika, dengan latar belakang pekerjaan dan jabatan ikut terlibat dalam gerakan ini. Melalui bidang politik, ekonomi, seni seperti astra, music dan teater, mereka bersama-sama berjuang untuk memperoleh persamaan hak dengan warga kaum kulit putih (Afro-Amerika). Tujuan utama mereka adalah untuk membebaskan Amerika dari segala tekanan dan keatidakadilan rasial (Encyclopaedia Britannica, 2020).

Langston Hughes adalah salah seorang eksponen secara terang-terangan terlibat di dalam pergerakan tersebut melalui ranah sastra. Masa ini desebut dengan pada masa periode Harlem renaissance. Terkenal sebagai sosok yang multitalenta, Hughes adalah seorang penulis berkulit hitam yang sangat berbakat, seorang pengarang, juga seorang penulis naskah (Encyclopaedia Britannica, 2014). Puisi "Negro" ditulis oleh Langston Hughes pada tahun 1922 masa dimana mulai munculnya gerakan menyuarakan Hak-Hak Sipil di Amerika Serikat. Pada masa ini juga orang kulit hitam di Amerika atau lebih populer disebut Afrika-Amerika sering diperlakukan dengan buruk karena latar belakang perbedaan warna kulit.

Puisi yang terdiri dari enam bait ini mencerminkan bagaimana medium puisi digunakan oleh penyair dalam menyampaikan salah satu peristiwa sejarah manusia, yaitu perbudakan kaum hitam yang direpresentasikan oleh bangsa Afrika. Setiap bait dari puisi masing-masing terdiri dari tiga baris, kecuali bait ke empat yang terdiri dari empat baris. Setiap baris pertama dimulai dengan "I/Aku" (anafora). Bait pertama dan terakhir memiliki ungkapan yang sama "I am a negro/Aku seorang negro", sedangkan empat bait lainnya dimulai dengan "I've been/Aku pernah". Penggunaan rasa "I"ve been/pernah" menunjukan hubungan antara masa lalu dengan masa sekarang. Dari puisi "Negro" dapat terlihat bahwa setiap baris kedua dan ketiga dari setiap bait diidentifikasi untuk mendukung baris pertama.

Secara umum dalam puisi ini Hughes mengidentifikasi dirinya dengan mengatakan "Saya seorang Negro/I am a negro". Secara tidak langsung Hughes memposisikan dirinya sebagai subjek atau pelaku dari cerita puisi tersebut. Dalam puisi ini Hughes menggambarkan orang Negro dengan menggunakan istilah "budak/ slave" "pekerja/worker," "penyanyi/singer," dan "korban/victim". Akhirnya Hughes menggunakan pengulangan bait pertama dan terakhir untuk menyimpulkan puisinya.

Tema yang menonjol dalam puisi ini adalah perbandingan antara status orang kulit putih dengan orang kulit hitam dari jaman dahulu hingga sekarang. Ditulis dari sudut pandang orang kulit hitam (Afrika-Amerika), puisi ini menggambarkan pengalaman perbudakan kaum kulit hitam sepanjang sejarah. Seperti yang tergambar dari puisi "Negro", orang Afrika mengalami penderitaan sejak jaman dulu dikarenakan perbedaan warna kulit dan menjadi bangsa terjajah. 
Tabel 1. Puisi "Negro" dan terjemahannya dalam bahasa Indonesia

\begin{tabular}{|c|c|}
\hline Bahasa Inggris & Bahasa Indonesia \\
\hline Negro & Negro \\
\hline $\begin{array}{l}\text { I am a Negro: } \\
\text { Black as the night is black, } \\
\text { Black like the depths of my Africa. }\end{array}$ & $\begin{array}{l}\text { Saya seorang Negro: } \\
\text { Hitam seperti malam hitam, } \\
\text { Hitam seperti dalamnya Afrika saya. }\end{array}$ \\
\hline $\begin{array}{l}\text { I've been a slave: } \\
\text { Caesar told me to keep his door-steps clean. } \\
\text { I brushed the boots of Washington. }\end{array}$ & $\begin{array}{l}\text { Saya pernah menjadi budak: } \\
\text { Caesar menyuruhku untuk menjaga tangga } \\
\text { pintunya tetap bersih. } \\
\text { Saya menyikat sepatu bot Washington. }\end{array}$ \\
\hline $\begin{array}{l}\text { I've been a worker: } \\
\text { Under my hand the pyramids arose. } \\
\text { I made mortar for the Woolworth Building. }\end{array}$ & $\begin{array}{l}\text { Saya pernah menjadi pekerja: } \\
\text { Di bawah tanganku piramida berdiri. } \\
\text { Saya membuat mortir untuk gedung Woolworth. }\end{array}$ \\
\hline $\begin{array}{l}\text { I've been a singer: } \\
\text { All the way from Africa to Georgia } \\
\text { I carried my sorrow songs. } \\
\text { I made ragtime. }\end{array}$ & $\begin{array}{l}\text { Saya pernah menjadi penyanyi: } \\
\text { Sepanjang jalan dari Afrika ke Georgia } \\
\text { Saya membawa lagu kesedihan saya. } \\
\text { Saya membuat music. }\end{array}$ \\
\hline $\begin{array}{l}\text { I've been a victim: } \\
\text { The Belgians cut off my hands in the Congo. } \\
\text { They lynch me still in Mississippi. }\end{array}$ & $\begin{array}{l}\text { Saya pernah menjadi korban: } \\
\text { Orang-orang Belgia memotong tangan saya di } \\
\text { Kongo. } \\
\text { Mereka masih menggantung saya di Mississippi. }\end{array}$ \\
\hline $\begin{array}{l}\text { I am a Negro: } \\
\text { Black as the night is black, } \\
\text { Black like the depths of my Africa. }\end{array}$ & $\begin{array}{l}\text { Saya seorang Negro: } \\
\text { Hitam seperti malam hitam, } \\
\text { Hitam seperti dalamnya Afrika saya. }\end{array}$ \\
\hline
\end{tabular}

Menjadi objek taruhan di bawah kekuasan raja Caesar atau di bawah kekuasaan raja Firaun Mesir, sebagai tawanan di negara asalnya sendiri Afrika, menjadi tawanan di bawah pemerintahan kerajaan Belgia di Kongo, adalah serangkaian penderitaan dan penindasan yang dialami oleh orang kulit hitam sepanjang sejarah. Terlebih lagi, perbudakan kulit hitam telah terjadi di berbagai penjuru bumi, di bawah berbagai konteks sosial dan politik, sehingga menjadikannya sebagai kutukan global bagi ras ini (Scott, 2006).

Melalui puisi "Negro" penyair berusaha untuk menghubungkan peristiwaperistiwa bersejarah melalui tema perbudakan dan penindasan yang menyertainya. Pertamatama hal ini dapat terlihat dari bait pertama yang berbicara tentang identitas penutur sendiri sebagai orang Afrika-Amerika. James Mercer Langston Hughes atau lebih popular dengan sebutan, Langston Hughes, lahir pada tanggal 1 Februari 1902 di daerah Joplin, Missouri, Amerika Serikat. Hughes meninggal dunia pada tanggal 22 Mei 1967 di New York, New York. Hughes adalah penulis Amerika keturunan Afrika yang merupakan tokoh penting dalam Harlem Renaissance. Harlem Renaissance adalah fase gerakan Negro Baru yang lahir pada awal abad ke-20 dan dalam beberapa hal mengantarkan kepada gerakan hak-hak sipil yang lebih besar untuk menuntut persamaan hak anatar warga kulit putih dan warga kulit hitam pada akhir 1940-an dan awal 1950-an.

Harlem Renaissance juga digunakan sebagai wadah untuk mencari persamaan hak dan penghapusan diskrimnasi warna kulit melalui media karya seni dan menjadikan orang Afrika-Amerika sebagai subjek tulisannya. Hughes telah menghasilkan banyak karya yang terdiri dari puisi, naskah drama, novel dan essay 
(Encyclopaedia Britannica, 2020). Sebagian besar karya Hughes merupakan representasi dari pengalaman kaum kulit hitam (Afrika) yang mengalami penderitaan, penindasan, dan diskriminasi warna kulit yang diakibatkan oleh praktek kolonialisme serta bentuk-bentuk perjuangan untuk menghapuskannya.

Puisi ini menggunakan kata "black/ hitam" untuk menambah penekanan pada warna kulit sebagai identitas utama orang Afrika. Sementara kata-kata "Caesar" dan "Washington" pada bait ke dua digunakan untuk menunjukan simbol kekuasaan yang diwakili oleh kaum kulit putih dalam hal ini bangsa Eropa. Puisi ini memberikan gambaran bahwa kulit putih lebih mendominasi dan berada dalam posisi di atas kulit hitam. Dominasi ini tidak hanya berlangsung di Amerika saja, tetapi sudah berlangsung selama beratus-ratus tahun di benua Eropa.

Dominasi kulit putih dapat dilihat pada penggalan puisi "Caesar told me to keep his door-steps clean/ Caesar menyuruhku untuk menjaga tangga pintunya tetap bersih". Dari bait puisis ini dapat terlihat bahwa bangsa kulit hitam telah menjadi budak atau hamba sahaya sejak jaman kerajaan Caesar di Eropa. Sementara dalam baris puisi "I brushed the boots of Washington/Saya menyikat sepatu bot Washington" menunjukan bahwa status warga kulit hitam sebagai seorang budak dan hamba sahaya tetap berlangsung pada kurun waktu berikutnya ketika mereka bemigrasi ke benua Amerika.

Puisi ini juga memperlihatkan bagaimana orang-orang Afrika diperlakukan melalui praktek perbudak-an di sepanjang masa. Mereka tidak dihormati ketika mereka menjadi budak dan bahkan setelah perbudakan dihapuskan.

Praktek perbudakan dan penindasan tercermin pada bait berikutnya. Bait ketiga dari puisi ini berbunyi "Under my hand the pyramids arose/ Di bawah tanganku piramida berdiri" dan "I made mortar for the Woolworth Building /Aku membuat mortir untuk bangunan Woolworth." Dua baris ini menunjukkan kontribusi yang dibuat orang Afrika di masa lalu sebagai pekerja keras. Kedua baris ini juga menunjukan bahwa para budak bangsa Afrika telah melakukan berbagai pekerjaan berat dan kasar dalam kurung waktu yang sangat panjang mulai dari membangun piramida di zaman Meisn kuno sampai membangun gedung Woolworth di Amerika pada masa yang lebih modern.

Kontribusi bangsa kulit hitam dalam membangun peradaban telah luput dari liputan sejarah dan peran mereka pun terlupakan oleh hegemoni kekuasaan bangsa kulit putih. Hal ini sesuai dengan dengan pernyataan Ashcroft dkk (1985) bahwa postkolonialisme menegaskan perjuangan yang muncul sebagai akibat dari dominasi suatu budaya terhadap budaya lainnya. Budaya kaum yang terjajah ini ditekan, ditaklukkan, dan seringkali dihilangkan dari sejarah oleh kaum penjajah.

Disamping praktek perbudakan, peristiwa penindasan dan penyiksaan telah menjadi pengalaman hitam kolektif di bawah kekuasaan bangsa Eropa. Serangkaian pekerjaan mulai dari membersihkan tangga pintu, menyikat sepatu bot, bekerja keras sebagai buruh kasar, budak hitam dan bangsa Afrika ditolak martabat mereka sepanjang sejarah.

Bentuk-bentuk penghinaan yang telah mereka terima termasuk mutilasi anggota badan, kurungan dirantai di barak kapal, dll. Seperti yang tercermin dalam bait puisi "The Belgians cut off my hands in the Congo/ Orang-orang Belgia memotong tangan saya di Kongo". Praktek pemutilasian anggota badan seperti yang terjadi di Congo adalah salah satu bentuk manifestasi penyiksaan terhadap kaum kulit hitam seagai hukuman terhadapa mereka karena tidak dapat memenuhi target dalam pengumpulan hasil bumi yaitu karet. (Negro, 2020).

Pada baris berikutnya "They lynch me still in Mississippi/Mereka masih menggantung saya di Mississippi" menunjukan bahwa penindasan dan penderitaan yng dihadapi oleh orang kulit hitam masih terus berlangsung sampai ke dekade berikutnya dimana orangorang Afrika bermigrasi ke benua Amerika. Sebagai seorang pelaku sejarah dan sekaligus penulis puisi, Hughes menunjukkan bahwa 
kesulitan yang dihadapi orang kulit hitam masih ada sampai sekarang dan menurut pandangannya hal-hal seperti ini perlu diubah dan bahkan dihilangkan.

Bait berikutnya menyinggung orang Afrika yang datang dari Afrika ke benua Amerika untuk dijadikan budak. Perbudakan di benua Amerika berawal ketika para budak Afrika pertama kali dibawa ke koloni Amerika Utara di Jamestown, Virginia, pada tahun 1619 untuk membantu dalam produksi tanaman yang menguntungkan seperti tembakau. Perbudakan dipraktekan di seluruh koloni Amerika di abad 17 dan 18, dan budak Afrika-Amerika membantu membangun fondasi ekonomi bangsa yang baru di benua Amerika (Harian Sejarah, 2017).

Dilain fihak, praktek perbudakan atau diskriminasi rasial juga maih dirasakan oleh orang-orang Amerika keturunan Afrika amapai awal abad ke-20. Hal ini dapat dilihat dari kalimat berikut ini: "All the way from Africa to Georgia/ Jauh dari Afrika ke Georgia". Malalui pernyataan ini perbudakan dan penindasan tidak hanya terjadi di negara asalnya Afrika tetapi juga terjadi di Georgia, Amerika Serikat. Dimana di Amerika sendiri warga Amerika keturunan Afrika diperlakukan tidak adil dan bahkan diposisikan sebagai masyarakat kelas dua dengan berbagai macam diskriminasi.

Diskriminasiadalahtindakanyangtidak menguntungkan terhadap orang-orang karena mereka adalah anggota kelompok etnis tertentu (McLemore, 1983). Diskriminasi tersebut terjadi dalam bidang pendidikan, pemerintahan federal dan negara bagian, bidang hukum, baik yang tertulis maupun implementasinya, bidang kesehatan yang memberikan pelayanan kesehatan dan pengalokasian dana yang tidak adil terhadap etnik minoritas seperti etnik AfroAmerika (Tyson, 2006).

Baris terakhir dalam bait berbunyi, "I made ragtime /Saya membuat musik" menunjukkan bahwa orang-orang Amerika keturunan Afrika yang tinggal di Amerika mengekspresikan penderitaan dan pengalaman pahit menjadi ojek penindasan melalui lagu atau karya seni. Dimana melalui lagu tersebut sebagai ungkapan kesedihan atas penderitaan yang selama berabad-abad mereka rasakan. Hal ini dibuktikan sendiri oleh sang penulis yang merupakan seniman keturunan Amerika-Afrika yang berkiprah pada masa Harlem Renaisance di awal tahun 1920an. Hughes mencoba untuk merespon praktek perbudakan terhadap kaum leluhurnya melalui ungkapan karya seni seperti puisi, lagu, naskah drama, novel, dan artikel (Hernton, 2014).

Bait terakhir adalah pengulangan dari bait yang pertama. Penulis memakai ulang kata "Negro" untuk memperkuat praktek penindasan yang dialami oleh bangsa kulit hitam. Kata "Negro" juga menunjukan bahwa orang kulit hitam memiliki pengalaman yang kelam dan hitam seperti malam. "Black as the night is black/Hitam seperti malam hitam,", memberi pembaca gagasan bahwa "hitam" sama gelapnya dengan "malam". "Black like the depths of myAfrica/Hitam seperti dalamnya Afrika saya" menciptakan karakter kaum hitam yang penuh dengan misteri akan perjalanan panjangnya sebagai kaum bangsa terjajah dan mnejadi objek perbudakan sepanjang sejarah.

Pengulangan pada bait terakhir ini memberi pembaca kesempatan untuk merenungkan makna perjuangan bangsa Afrika sebagai bangsa terjajah dan termajinalkan akibat praktek colonial dan perbedaan warna kulit. Melalui puisi ini penulis ingin agar pembaca memiliki emosi dan rasa empati terhadap cara orang Afrika-Amerika diperlakukan (Hernton, 2014).

Berdasarkan analisi puisi negro, bentuk diskriminasi rasial yang diakibatkan oleh praktek kolonialisme bangsa Eropa (kulit putih) terhaap bangsa Afrika (kulit hitam) terlihat dari penggunaan kata-kata "slave", "woker", "victim", dan "singer". Bangsa kulit hitam telah mengalami penindasan dalam bentuk perbudakan, pekerja paksa/keras, korban kekejaman, serta pekerja seni yang mengekspresikan pederitaan dan pengalaman sejarah leluhurnya melalui lagu.

Salah satu upaya yang dilakukan oleh bangssa terjajah untuk berjuang melawan praktek kolonialime ini adalah menyuarakan protes dan menyuarakan ketidakadilan yang terjadi seperti yang dilakukan oleh Langston 
Hughes melalui karya sastra. Kelak di kemudian hari gerakan menyuarakan keadilan ini mengarah kepada gerakan yang lebih besar lagi yang menghasilkan wacana dihapuskannya praktek perbudakan di Amerika Serikat dan mempromosikan persamaan hak atas segala macam ras dan warna kulit (Ensyclopedia Britanica, 2020).

Praktek kolonialisme di negara jajahan telah memberikan dampak buruk serta derita berkepanjangan yang dirasakan oleh rakyat bangsa terjajah seperti yang tergambar di dalam pusis "Negro". Dari peristiwa sejarah kolonialisme ini maka lahirlah karya sastra poskolonial yang bertujuan untuk menyuarakan keadilan dan meruntuhkan dogma-dogma yang selama ini membelenggu kaum terjajah yang pada umumnya digencarkan oleh negaranegara barat. Tulisan-tulisan atau karya sastra yang muncul dan dikaji dari sudut pandang poskolonial pada umumnya merupakan tulisan dari budaya bangsa-bangsa yang pernah dijajah seperti Australia, Selandia Baru, Afrika, Amerika Selatan, dan bangsa-bangsa bekas jajahan lain atau masyarakat yang dulu didominasi oleh kekuatan lain (Emzir \& Rohman, 2017).

\section{SIMPULAN}

Poskolonialisme memberikan perspektif baru dalam melihat karya sastra terutama yang terkait dengan dua bangsa dan dua budaya yang tidak tepat posisi 'oposisi biner'nya. Artinya yang satu mendominasi dan yang lain menjadi didominasi. Inilah yang terjadi juga dalam karya sastra-karya sastra poskolonial, yang sangat diwarnai dengan pertentangan dua budaya yang menjadi ciri dari karya sastra tersebut. Dari pusi "Negro" dapat disimpulkan bagaimana posisi kaum kulit putih sangat mendominasi terhadap kaum kuit hitam. Dimana kaum kulit hitam dimarjinalkan dan diperlakukan sebagai bangsa kelas dua. Berbagai atribut yang dilekatkan kepada kaum kulit hitam diantaranya yaitu sebagai budak, pekerja keras/kasar, serta korban dari penindasan.

\section{DAFTAR PUSTAKA}

Ashcroft, B., Griffiths \& Tiffin. (2003). Menelanjangi Kuasa Bahasa: Teori dan Praktik Sastra Poskolonial. terj. "The Empire Writes Back: Theory"

Bahri, D. (1996). Introduction to Postcolonial Studies. http://www.english.emory. edu/Bahri/Intro.html

Bressler, C. E. (1999). "Postcolonialism: the Empire Writes Back" dalam Literary Criticism: An Introduction to Theory and Practice. New Jersey: Prentice Hall.

Creswell, J. W. (2012). Educational Research: Planning, Conducting, and Evaluating; Quantitative and Qualitative Research. Singapore: Pearson.

Emzir \& Rohman, S. (2017). Teori dan Pengajaran Sastra. Depok: Rajawali Pers.

Encyclopaedia Britannica. (2020). Langston Hughes American poet https://www. britannica.com/biography/LangstonHughes).

Harian Sejarah. (2017). Sejarah Perbudakan Di Amerika. https://www.hariansejarah. id/2017/04/sejarah-perbudakan-diamerika.html)

Hernton, C. (2014). The Poetic Consciousness of Langston Hughes from Affirmation to Revolution. Gale Net. Gale Net, n.d. Web. 18 Apr. 2014.

Intan, T. (2020). Teori Poskolonial Dalam Kajian Sastra Frankofon. https:// www.academia.edu/34059840/ TEORI_POSKOLONIAL_DALAM_ KAJIAN_SASTRA_FRANKOFON.

Iswalono, S. (2014). Resistensi Dan Respon Etnik Afro-Amerika Atas Marjinalisasi Etnik Anglo-Amerika Dalam PuisiPuisi Karya Hughes. https://journal. uny.ac.id/index.php/litera/article/ view/1910

Karim, A. R. (2015). Biografi dan Pemikiran Edward W. Said. https://rahimark. wordpress.com/2015/10/23/ biografi-dan-pemikiran-edward$\mathrm{w}-\mathrm{s}$ aid/ $\#: \sim:$ te $\mathrm{xt}=\mathrm{Edw}$ ard $\% 20$ W. $\% 20 \mathrm{~S}$ a id $\% 20$ ad a 1 a h $\% 20$ 
seorang,dunia $\% 20$ Arab $\% 20$ yang $\% 20$ sangat $\% 20$ cekatan.

Kusmarni, Y (2019). Teori Postkolonial: Suatu Kajian Tentang Teori Poskolonial Edward W. Said. http://sejarah.upi. edu/artikel/dosen/teori-postkolonial/

Nurhadi. 2007. Poskolonial: Sebuah Pembahasan. Artikel no 47 dipresentasikan dalam Seminar Rumpun Sastra di FBS UNY, Yogyakarta pada 7 Desember 2007. http://staffnew.uny.ac.id/upload/ $132236129 / \mathrm{pene} 1 \mathrm{itian/}$ POS K OLONIAL + SEBUA H + PEMBAHASAN.pdf.

Riana, N. M. dkk. (2015). Langston Hughes' Selected Poems In Riffaterre's Perspective (Puisi-Puisi Langston Hughes Terpilih Dalam Perspektif Riffaterr. Publikasi Budaya. Vol. 3 No.2. Mei 2015. http://jurnal.unej. ac.id/index.php/PB/article/view/4589

Ratna, N. K. (2008). Postkolonialisme Indonesia: Relevansi Sastra. Yogyakarta: Pustaka Pelajar.

Said, E. W. (2001). Orientalisme. Terj. Orientalism, 1978. Bandung: Penerbit Pustaka.
Santosa, P. (2012). Kritik Postkolonial: Jaringan Sastra atas Rekam Jejak Kolonialisme. Badan Pengembangan dan Pembinaan Bahasa. https://www.researchgate.net/ publication/327134028

Setiawan, A. K. (2007). Wacana Postkolonial Dalam Roman Larasati Karya Pramoedya. Proceding Seminar Nasional Rumpun Sastra FBS UNY http://staff.uny.ac.id/sites/default/ files/132299490/poskolonialisme $\% 20$ dalam $\% 20$ sastra\%20afro-amerika.pdf

Scott, J. (2006). Socialist Joy in the Writing of Langston Hughes. Columbia, MO: U of Missouri.

Tyson, L. (2006). Critical Theory Today: A User-Friendly Guide. Second ed. New York: Routledge.

Wilujeng, L. L. dan Wirono, A. (2003). Langston Hughes's Poem as Manifestation of Racial Protest tudi Tentang Puisi-puisi Langston Hughes sebagai Perwujudan Protes Ras. Sosiohumanika, Vol 16 No. 2 Mei 2003. http://i-lib.ugm. ac.id/jurnal/detail.php?dataId=2207 http://langston-and-us.over-blog.com/ article-negro-64559481.html 